Journal of Tropical Ecology

http://journals.cambridge.org/TRO

Additional services for Journal of Tropical Ecology:

Email alerts: Click here

Subscriptions: Click here

Commercial reprints: Click here

Terms of use : $\underline{\text { Click here }}$

\title{
Soil texture and altitude, respectively, largely determine the floristic gradient of the most diverse fog oasis in the Peruvian desert
}

Jannes Muenchow, Simon Hauenstein, Achim Bräuning, Rupert Bäumler, Eric Frank Rodríguez and Henrik von Wehrden

Journal of Tropical Ecology / Volume 29 / Issue 05 / September 2013, pp 427 - 438

DOI: 10.1017/S0266467413000436, Published online: 11 July 2013

Link to this article: http://journals.cambridge.org/abstract S0266467413000436

How to cite this article:

Jannes Muenchow, Simon Hauenstein, Achim Bräuning, Rupert Bäumler, Eric Frank Rodríguez and Henrik von Wehrden (2013). Soil texture and altitude, respectively, largely determine the floristic gradient of the most diverse fog oasis in the Peruvian desert. Journal of Tropical Ecology, 29, pp 427-438 doi:10.1017/S0266467413000436

Request Permissions : $\underline{\text { Click here }}$ 


\title{
Soil texture and altitude, respectively, largely determine the floristic gradient of the most diverse fog oasis in the Peruvian desert
}

\author{
Jannes Muenchow ${ }^{1}$, Simon Hauenstein, Achim Bräuning, Rupert Bäumler, Eric Frank Rodríguez and \\ Henrik von Wehrden
}

Institute of Geography, University of Erlangen-Nuremberg, Kochstr. 4/4, 91054 Erlangen, Germany

(Received 11 March 2013; revised 12 June 2013; accepted 13 June 2013; first published online 11 July 2013)

\begin{abstract}
Studying species turnover along gradients is a key topic in tropical ecology. Crucial drivers, among others, are fog deposition and soil properties. In northern Peru, a fog-dependent vegetation formation develops on mountains along the hyper-arid coast. Despite their uniqueness, these fog oases are largely uninvestigated. This study addresses the influence of environmental factors on the vegetation of these unique fog oases. Accordingly, vegetation and soil properties were recorded on $664 \times 4$-m plots along an altitudinal gradient ranging from 200 to $950 \mathrm{~m}$ asl. Ordination and modelling techniques were used to study altitudinal vegetation belts and floristic composition. Four vegetation belts were identified: a low-elevation Tillandsia belt, a herbaceous belt, a bromeliad belt showing highest species richness and an uppermost succulent belt. Different altitudinal levels might reflect water availability, which is highest below the temperature inversion at around $700 \mathrm{~m}$ asl. Altitude alone explained $96 \%$ of the floristic composition. Soil texture and salinity accounted for $88 \%$. This is in contrast with more humid tropical ecosystems where soil nutrients appear to be more important. Concluding, this study advances the understanding of tropical gradients in fog-dependent and ENSO-affected ecosystems.
\end{abstract}

Key Words: altitudinal zonation, diversity gradient, dry tropics, edaphic gradient, ENSO, floristic modelling, La Niña, South America, spatial analysis, species richness

\section{INTRODUCTION}

Species richness and species turnover along environmental gradients are key topics in community ecology and biogeography (Terborgh 1971, Whittaker \& Niering 1965). For example, edaphic conditions, microclimate and species interactions structure vegetation composition at the local scale (Blundo et al. 2012). These factors often change rapidly along altitudinal gradients. Therefore, montane ecosystems constitute an excellent natural laboratory to investigate the influence of environmental gradients on species assemblages (Muenchow et al. 2012). The importance of these factors naturally depends on the climatic, geologic, topographic and historical setting of an ecosystem (Blundo et al. 2012). For instance, soil conditions govern the composition of tropical rain forests (Tuomisto et al. 2003). To a lesser extent, edaphic conditions also play a role in montane and tropical dry forests (Peña-Claros et al. 2012, Soethe et al. 2008). Climate is probably more important in structuring

\footnotetext{
${ }^{1}$ Corresponding author. Email: jannes.muenchow@fau.de
}

vegetation in wet montane forests (Ashton 2003, Beck et al. 2008), and water availability primarily determines tropical dry forest communities (Espinosa et al. 2011, Muenchow et al. 2013a).

Arid to semi-arid ecosystems compose large parts of the tropics, yet tropical research primarily focuses on more humid ecosystems. In South America, a large body of literature is available for the Andes and the Amazonian lowlands (Pitman et al. 2011). The dry western coastal areas of South America, however, remain largely neglected (Espinosa et al. 2011). Different El Niño Southern Oscillation (ENSO) phases bring occasionally rainfall and higher fog intensities (Dillon \& Rundel 1990, Muenchow et al. 2013b). Within this setting, coastal mountains represent islands of vegetation that contrast with the barren desert (Dillon et al. 2003, Schulz et al. 2011). The fog-dependent vegetation formation found on these mountains is locally termed lomas (Dillon $e t$ al. 2003; Figure 1). Fog deposition is a crucial driver of diversity in many tropical coastal and mountainous ecosystems by increasing hydrological and chemical input (González et al. 2011, Liu et al. 2004, Rollenbeck et al. 2011). 

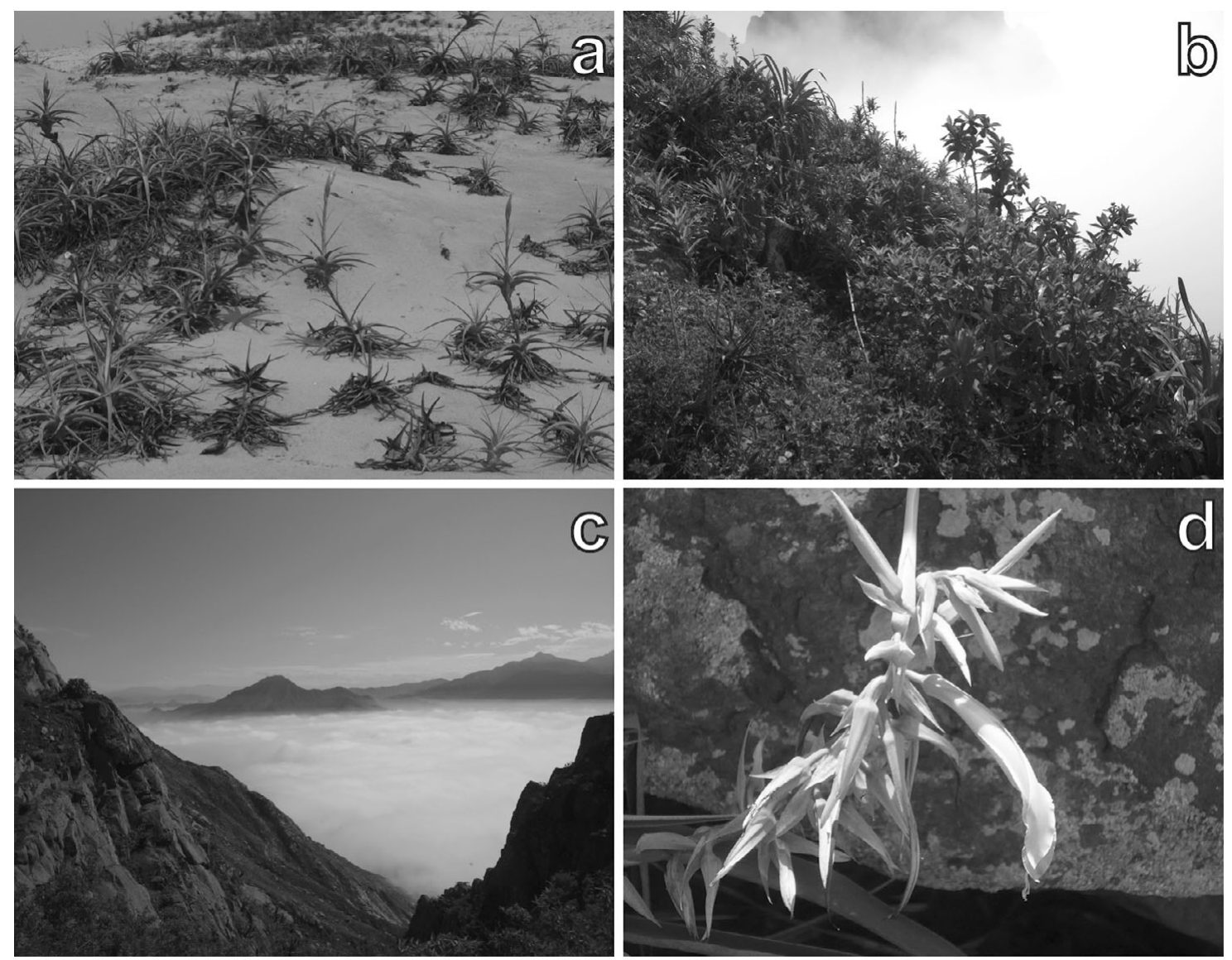

Figure 1. Photos from the study mountain, Mount Campana. Tillandsia species residing in sandy habitat (a). Characteristic vegetation structure of a plot (657 m asl) located in the bromeliad belt (b). The temperature inversion at c. $700 \mathrm{~m}$ asl photographed from Mount Campana (c). Pitcairnia lopezii (Bromeliaceae) - a species endemic to Mount Campana (d).

Although numerous studies have revealed a relationship between altitude and species composition, only one study on fog oases considered topographical and remotely sensed variables to explain species richness (Muenchow et al. 2013b). Secondly, soil properties are well known to structure vegetation composition in tropical ecosystems such as rain forests (Laurance et al. 2010), montane forests (Soethe et al. 2008), tropical dry forests (Peña-Claros et al. 2012) and savannas (Sarmiento et al. 2006). Although water is the main limiting factor in dry ecosystems, nutrients are sometimes equally important in structuring vegetation (Ronnenberg \& Wesche 2011). Yet, the effects of soil properties on the floristic composition of fog oases are still uninvestigated.

Accordingly, we hypothesized that: (1) the floristic composition follows the altitudinal gradient of a Peruvian fog oasis in a non-linear fashion due to different fog moisture levels; (2) edaphic variables explain as much of the vegetation composition as topographic variables, because both sets of variables are likely to follow the humidity-altitude gradient.

\section{METHODS}

\section{Study area}

The study area, Mount Campana, is located in North Peru close to Trujillo (Figure 2). The mountain is mainly composed of granitic material (Rodríguez 1996) forming steep slopes and delivering sharp-edged weathering products. Sand-transporting trade winds accumulate dune fields at the base of the southern slope. Cattle trampling is clearly evident on the slopes. Other human activities include litter pollution in the course of the expansion of the city of Trujillo, burning and removal of vegetation, particularly Tillandsia (Figure 1a) as well as woody species. Annual precipitation varies between 7 and $150 \mathrm{~mm} \mathrm{y}^{-1}$ along the studied transect (Sagástegui et al. 1988) and is restricted to the austral winter months (JulyOctober). Additionally, ENSO causes climate variability. During the austral winter, fog precipitation is common and increases the water availability for plants. In addition, El Niño and La Niña increase water availability on a regular basis (Dillon \& Rundel 1990, Muenchow et al. 


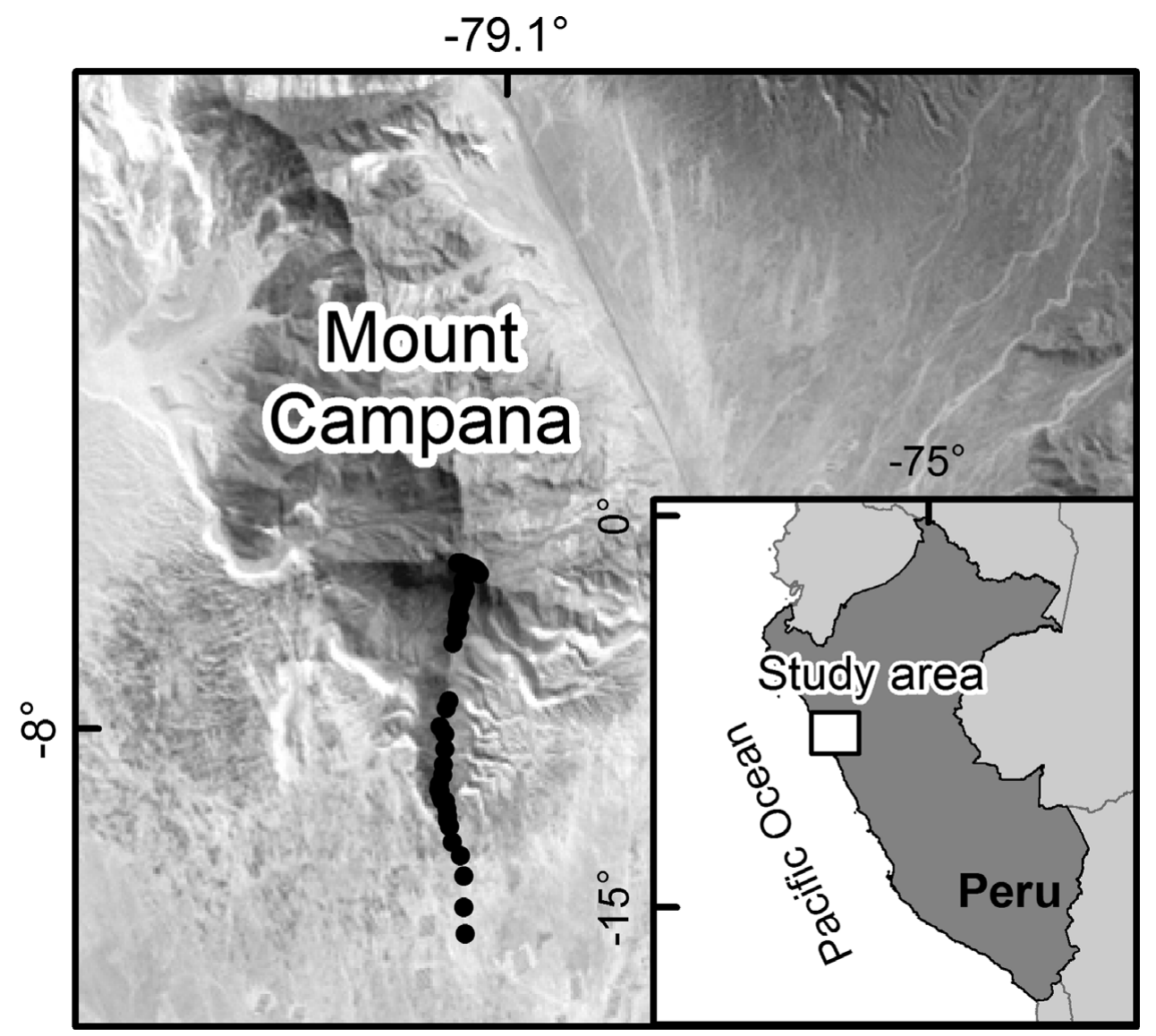

Figure 2. Landsat image (path: 9; row: 66; acquisition date: 27 September 1987; derived from: https://lpdaac.usgs.gov/) showing the study area. Black dots represent sampling units along the altitudinal transect in the study area on Mount Campana.

2013b). To date, 230 plant species (168 phanerogams, 62 cryptogams) have been recorded on Mount Campana (Sagástegui et al. 1988), making this the most diverse fog oasis along the western coast of South America (Dillon \& Rundel 1990, Rundel \& Dillon 1998).

\section{Vegetation sampling, soil analysis and variable assessment}

Vegetation was sampled along an altitudinal transect (200-950 $\mathrm{m}$ asl) on the fog-exposed, southern slope of Mount Campana. Plots of $4 \times 4 \mathrm{~m}$ (Figure 1b) were aligned at intervals of $15 \mathrm{~m}$ altitudinal difference. In accordance with two reconnaissance surveys we intensified the sampling frequency in the main vegetation belt $(545-770 \mathrm{~m}$ asl) by reducing the interval to $7.5 \mathrm{~m}$ altitude difference reaching a plot total of 66 . The vegetation survey was carried out during the flowering period of an exceptional La Niña year (September 2011; http://www.cpc.ncep.noaa.gov/products/ analysis_monitoring/ensostuff/ensoyears.shtml). We recorded the percentage cover of all vascular plant species at each site. Nomenclature follows the
Missouri Botanical Garden Tropicos online database (http://www.tropicos.org/).

Bulk soil samples were collected between 15 and $30 \mathrm{~cm}$ depth in each plot. The fine-earth fraction was calculated as the relative percentage by weight of material $<2 \mathrm{~mm}$ in diameter and skeletal content. Soil pH was measured in a solution of $5 \mathrm{~g}$ soil to $12.5 \mathrm{ml}$ $\mathrm{CaCl}_{2}$, and electrical conductivity in a solution of $5 \mathrm{~g}$ soil to $25 \mathrm{ml}$ distilled water. Carbonate and nitrogen concentrations were analysed according to Schlichting et al. (1995) via a LecoTrueSpec C/N-analyser. Sand fractions were obtained by sieving after dispersion. The remaining silt and clay contents were analysed in a micrometrics SediGraph 5120. Beforehand, organic matter was destroyed if exceeding $5 \%$ mass volume by $10 \% \mathrm{H}_{2} \mathrm{O}_{2}$ solution, and the electrical conductivity reduced to less than $50 \mu \mathrm{S}$ by repeated washing in distilled water. Water-soluble P was measured according to Page et al. (1982) using a spectrophotometer (DR 5000 UV-VIS; Schlichting et al. 1995). Exchangeable cations (Ca, $\mathrm{Mg}, \mathrm{K}$ and $\mathrm{Na}$ ) were extracted with $\mathrm{NH}_{4} \mathrm{Cl}$, and further analysed by atomic absorption spectrometry (Thermo AAS-Spectrometer SOLAAR M6). To meet assumptions of normality, we log-transformed electrical conductivity, 
organic matter as well as the root content and took the square root of phosphorus concentration.

Altitude was extracted from a digital elevation model (ASTER GDEM, derived from: https://lpdaac.usgs.gov/). The Normalized Differenced Vegetation Index (NDVI) was calculated from a Landsat scene (path: 9; row: 66; acquisition date: 27 September 1987; derived from: https://lpdaac.usgs.gov/).

\section{Statistical analyses}

Biodiversity of vascular plants was determined by Whittaker's three diversity measures (Whittaker 1972): alpha diversity is the species number per plot, gamma diversity is the total species number over all plots and beta diversity is the ratio of gamma diversity and mean alpha diversity minus one. Moreover, we performed a Detrended Correspondence Analysis (DCA; Hill \& Gauch 1980) on the presence-absence matrix of species. Calculating the length of the first axis in standard deviations, we obtained a second measure of beta diversity. A length of four standard deviations corresponds to a complete species turnover.

To identify the change of the floristic composition along the altitudinal gradient (hypothesis 1), we applied the rank-based, non-metric multidimensional scaling (NMDS). NMDS aims to reduce the difference between the distances of the original matrix and its counterparts found in ordination space. This difference is expressed as stress. Low stress values $(<15)$ indicate a good fit (Kruskal 1964). Another measure of fit is the coefficient of determination between the distances of the original species dataset and the distances of the synthetic ordinal dataset. We used the Bray-Curtis distance of our species table and a random starting configuration to initialize the ordination. Post hoc, soil variables significant in accordance with our modelling were fitted into the ordination space.

We employed model-based clustering to quantify the vegetation belts along the altitudinal gradient. This approach has already yielded promising results in another study (Muenchow et al. 2013b). It has two fundamental advantages over classical cluster techniques commonly applied in vegetation science (Wesche \& Wehrden 2011): (1) the number of cluster classes is objectively chosen by the Bayesian Information Criterion (BIC) for the expectation-maximization (EM) algorithm in a hierarchical manner (Fraley \& Raftery 2002); (2) it avoids the zero-inflated species matrix by using environmental predictors instead. We chose altitude and NDVI as predictors in the model-based clustering. Subsequently, we used the altitudinal range of each cluster class to identify vegetation belts. Additionally, we searched for the species occurring exclusively and most frequently in the respective cluster classes.
We modelled the vegetation composition as a function of soil covariates. As a first step, we extracted the NMDS scores of the first axis, which already explained $85 \%$ of the observed variance, and thus represented the main floristic gradient. Secondly, we used these scores as response variable in a multiple regression analysis (Muenchow et al. 2013a). There is a non-linear relationship between the response and the $<2-\mathrm{mm}$ soil fraction (Figure 3, hypothesis 1). Consequently, the fine-earth fraction entered the modelling in the form of a polynomial function of the second order. Moreover, the relationship between the fine-earth fraction and electrical conductivity changes along the altitudinal gradient, which required the addition of an interaction term. Comparing the full model and a model without the interaction term, the $F$ Statistic confirmed the interaction to be significant at the $5 \%$ level. The succeeding model selection followed the hypothesis testing approach, dropping one variable at a time until only significant terms remained in the model. The final model was of the form:

$$
\begin{aligned}
\text { Scores }_{i} \sim & \mathrm{N}\left(\mu_{i}, \sigma^{2}\right) \\
\mu_{i}= & \alpha+\beta_{1} \times s_{i}+\beta_{2} \times \text { log.ec }_{i}+\beta_{3} \\
& \times{\text { fine earth } \text { fraction }_{i}+\beta_{4}} \\
& \times{\text { fine earth } \text { fraction }_{i}^{2}+\beta_{5}} \\
& \times{\text { fine earth } \text { fraction }_{i} \times \text { log.ec }_{i}}^{\text {fin }}
\end{aligned}
$$

where Scores are the NMDS scores of the first axis, $i$ is the $i$ th observation, $\beta$ is the estimated slope of the corresponding covariate, $\alpha$ is the intercept, log.ec is the logarithm of electrical conductivity and fine-earth fraction $\times$ log.ec refers to the interaction between the fine-earth fraction and electrical conductivity. Model inspection showed no violation of the model assumptions. We assessed the relative variable importance by comparing the relative adjusted $R^{2}$ change associated with dropping one term at a time.

Furthermore, we were interested in which topographic covariates can serve as a surrogate for soil properties (hypothesis 2). Accordingly, we performed variation partitioning (Borcard et al. 1992). The results of two multiple linear regressions entered the variation partitioning. Regression 1 corresponds to the final model described above. Regression 2 used altitude and its square term, as there is a unimodal relationship with the response (NMDS scores of the first axis; Figure 4a). A permutation test (999 runs) produced significance levels of the pure fractions altitude and soil.

All statistical analyses were conducted in the open-source software R (http://www.r-project.org/) using its packages lattice (Sarkar 2008), mclust (Fraley \& Raftery 2002), raster (http://CRAN.Rproject.org/package $=$ raster) and vegan (http://CRAN.Rproject.org/package $=$ vegan). 


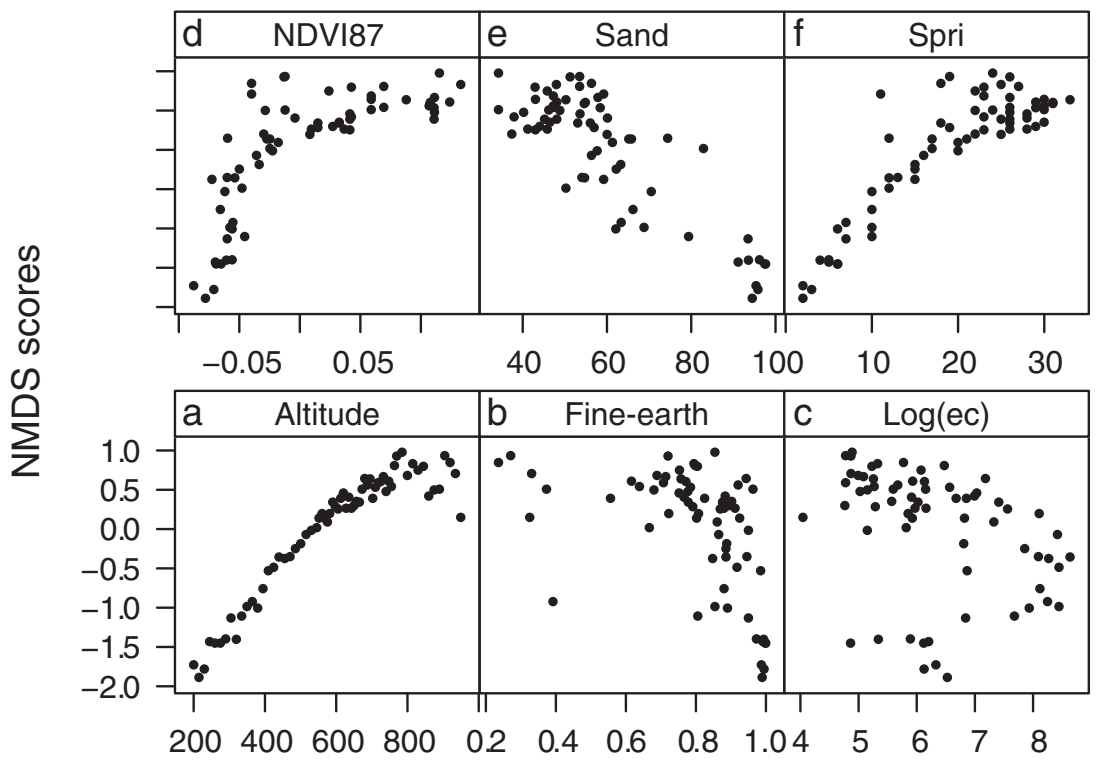

\section{Covariates}

Figure 3. Scatterplot displaying all variables used in the statistical analyses plotted against the NMDS scores of the first axis. Each dot represents a visited plot on Mount Campana. Altitude (a), fine-earth fraction (b), the logarithm of electrical conductivity (c), the Normalized Difference Vegetation Index obtained in 1987 (d), the sand fraction (e), and plant species richness per plot (f).
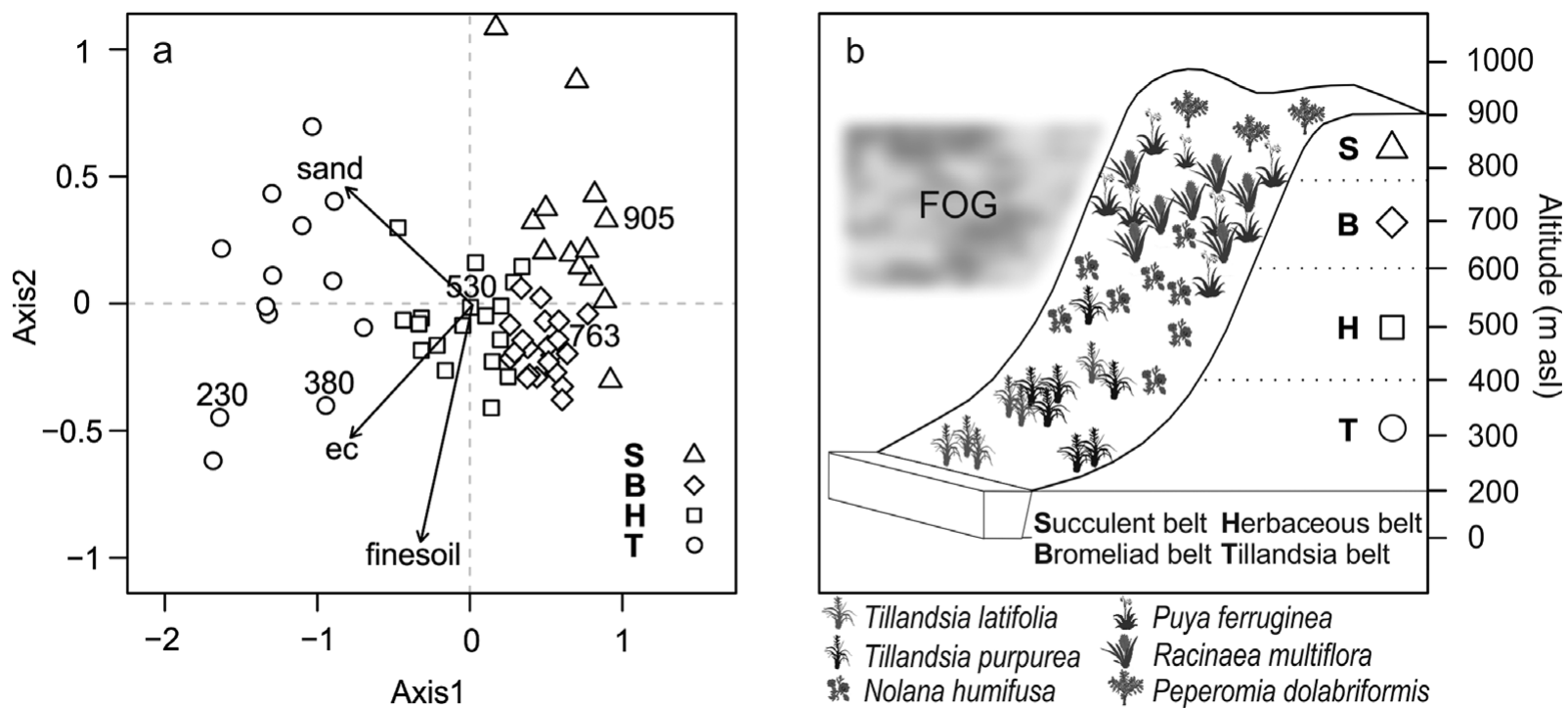

Figure 4. Altitudinal vegetation belts of the Mount Campana. NMDS ordination and cluster classes according to the model-based clustering (Table 1). Only those soil variables were fitted that were rendered significant in a regression analysis. Numbers above symbols represent altitude in $\mathrm{m}$ asl (a). Conceptual model of vegetation belts as derived from the model-based clustering. Species' families can be found in Appendix 1 (b). ec, Electrical conductivity.

\section{RESULTS}

\section{Description of vegetation and soil along the altitudinal gradient}

We recorded 88 vascular plant species over the whole elevation gradient (Appendix 1). Plant species richness varied between 2 and 33 per plot $($ mean $=19)$. Showing more than one complete species turnover in the DCA (4.15), beta diversity was intermediate, which is also in accordance with Whittaker's beta (4.87). Species richness followed a unimodal pattern along the altitudinal gradient with highest values around $700 \mathrm{~m}$ asl (Figure 5).

Some soil variables also exhibited the mid-domain effect such as electrical conductivity and organic matter. Contrasting, other soil properties showed a decreasing 


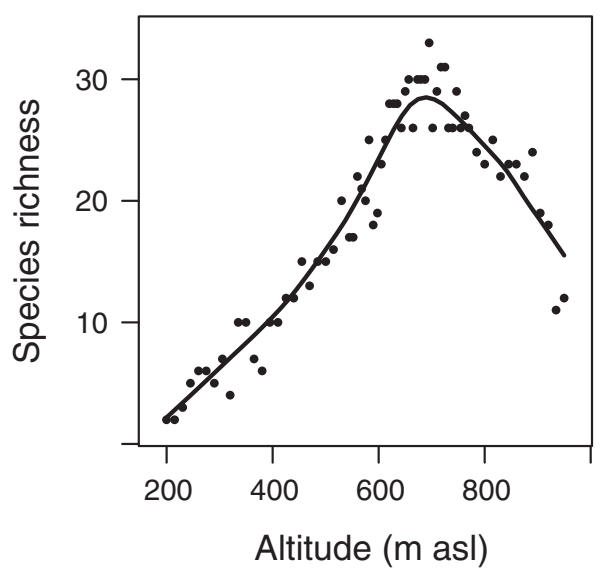

Figure 5. Species richness along the altitudinal gradient of the Mount Campana. A line smoother was added to aid visual inspection.

trend (e.g. sand fraction and fine-earth fraction) or barely any relationship with altitude (e.g. sodium and phosphorus concentrations).

\section{Floristic gradient}

The NMDS ordination was clearly able to distinguish the different vegetation belts along the altitudinal gradient (hypothesis 1, Figure 4). The length \pm SD of the first two axes were $2.8 \pm 1.7$ and $0.78 \pm 0.3$ respectively. The first axis showed a tight relationship with altitude and to a lesser degree with electrical conductivity. The second axis reflected mainly the fine-earth and the sand fractions (Figure 4). The NMDS achieved a stress of 9.5. The $R^{2}$ between the distances of the original dataset and the distances in ordinal space was $93 \%$.

\section{Vegetation belts and corresponding soil characteristics}

The model-based clustering detected four cluster classes (Table 1; Figure 4): a Tillandsia belt, a herbaceous belt, a bromeliad belt and a succulent belt. Sandy soils dominated the lowermost Tillandsia belt, which showed the lowest mean alpha diversity. Ascending upwards Tillandsia species were replaced by carpets of Nolana humifusa (Solanaceae; Table 1; Figure 4). Soils showed the first signs of humification and a brownish colour due to iron oxide release from primary minerals. The highest alpha diversity levels were reached in the bromeliad belt (Table 1; Figure 4). The coloured and perennial bromeliads Racinaea multiflora and Puya ferruginea dominated this belt (Figure 1b). Woody shrubs were prevalent, and trees remained almost absent. The highest portions of clay, soil organic matter and cations were found in this vegetation belt, indicating the most advanced soil development (Cambisols). By contrast, initial soils with a high portion of skeletal content dominated the uppermost succulent belt. Accordingly, alpha diversity decreased and drought-adapted species such as the succulent Peperomia dolabriformis (Piperaceae) regained dominance (Table 1; Figure 4).

\section{Explaining the floristic gradient using soil properties and altitude}

The sequential hypothesis testing revealed the following significant soil covariates: sand fraction, fine-earth fraction and its square term, electrical conductivity and the interaction between the fine-earth fraction and electrical conductivity. The sand fraction was clearly the most important single predictor in explaining the

Table 1. Model-based cluster classes. Only species with frequencies $>1$ were considered. Species' families can be found in Appendix 1. IQR, Interquartile range.

\begin{tabular}{|c|c|c|c|c|c|}
\hline Belt & $\begin{array}{c}\text { Median } \\
\text { altitude } \\
\text { (IQR) }\end{array}$ & $\begin{array}{c}\text { Number of } \\
\text { plots per } \\
\text { class }\end{array}$ & $\begin{array}{c}\text { Mean } \\
\text { species } \\
\text { number }\end{array}$ & Most frequent species & $\begin{array}{l}\text { Species unique to the } \\
\text { vegetation belt }\end{array}$ \\
\hline Tillandsia belt & $298(98)$ & 14 & 5.9 & Tillandsia latifolia & $\begin{array}{l}\text { Palaua malvifolia } \\
\text { Lycium americanum } \\
\text { Solanum multifidum } \\
\text { Tillandsia recurvata }\end{array}$ \\
\hline Herbaceous belt & $538(100)$ & 18 & 17.2 & $\begin{array}{l}\text { Nolana humifusa } \\
\text { Parietaria debilis }\end{array}$ & Vasquezia oppositifolia \\
\hline Bromeliad belt & $687(75)$ & 21 & 28.3 & $\begin{array}{l}\text { Fuertesimalva limensis } \\
\text { Parietaria debilis } \\
\text { Puya ferruginea } \\
\text { Racinaea multiflora }\end{array}$ & $\begin{array}{l}\text { Bowlesia palmata } \\
\text { Calceolaria utricularioides } \\
\text { Cyclanthera mathewsii } \\
\text { Oxalis corniculata } \\
\text { Solanum mochiquense }\end{array}$ \\
\hline Succulent belt & $860(90)$ & 13 & 20.9 & $\begin{array}{l}\text { Drymaria cordata } \\
\text { Parietaria debilis } \\
\text { Philoglossa purpureodisca } \\
\text { Solanum montanum }\end{array}$ & $\begin{array}{l}\text { Dalea nova } \\
\text { Ophryosporus peruvianus } \\
\text { Peperomia dolabriformis }\end{array}$ \\
\hline
\end{tabular}


floristic composition $\left(\mathrm{R}^{2}\right.$ decrease while dropping the sand fraction from the model $=41.3 \%$ ) followed by electrical conductivity $\left(\mathrm{R}^{2}\right.$ decrease $\left.=8.7 \%\right)$, the fine-earth fraction $\left(\mathrm{R}^{2}\right.$ decrease $\left.=3.7 \%\right)$, and the interaction term $\left(\mathrm{R}^{2}\right.$ decrease $=1.2 \%)$. The model reached a high goodnessof-fit (adjusted $\mathrm{R}^{2}=88 \%$ ).

Moreover, variation partitioning disclosed that altitude accounted for the complete fraction explained by soil properties $\left(\mathrm{R}^{2}=88 \%\right)$, and additionally contributed an extra amount of $8 \%$ (hypothesis 2). All pure fractions were highly significant $(\mathrm{P}<0.001)$ in accordance with a permutation test.

\section{DISCUSSION}

\section{Species richness and the influence of ENSO}

Mount Campana supports the most diverse fog oasis on a global scale (Dillon \& Rundel 1990). This is most probably due to the relatively high rainfall input in comparison with other fog oases (Muenchow et al. 2013b). As a consequence, several species are present which are unusual for deserts (Sagástegui et al. 1988). In addition, some bromeliads also have their southernmost distribution in the vicinity of Mount Campana (Rundel \& Dillon 1998). Finally, Mount Campana is the highest coastal mountain in Northern Peru, a region where El Niño exerts major influence (Bendix et al. 2011). It has been long argued that El Niño might trigger tree growth and enhance seedling survival (Lopez et al. 2006, Sitters et al. 2012, Squeo et al. 2006). The different episodes of ENSO are most probably the cause for much of the plant diversity of the South American fog oases. Most likely, they would be less diverse if ENSO episodes were absent (Dillon et al. 2003) as is the case for comparative sites in the Namib Desert (Lalley \& Viles 2005) and the Sonoran Desert (Rundel 1978). Interestingly, La Niña might have similar positive effects on fog oases as El Niño in terms of fostering diversity, primary productivity and seedling establishment, as cooler temperatures associated with La Niña increase condensation activity in coastal Peru (Muenchow et al. 2013b).

Generally, species richness showed a hump-shaped pattern along the studied altitudinal transect. Rahbek (2005) identified this pattern as the most abundant one in studies of altitudinal gradients. Apparently, it is valid for a wide range of organisms such as mosses (AhPeng et al. 2012), ferns (Kessler 2001), insects (Brehm et al. 2007), birds (Kattan \& Franco 2004), vascular plants (Grytnes \& Beaman 2006) and mammals (SanchezCordero 2001). Most prominently, ecological (Grytnes 2003) and historical reasons (Rahbek \& Graves 2001) served as explanation for this phenomenon, as well as geometry in form of the mid-domain effect (Colwell et al.
2004), which aroused remarkable controversy (Sandel \& McKone 2006). In our case, we ascribe the unimodal species richness behaviour to local climatic variability. At higher altitudes, water becomes increasingly available until the temperature inversion is reached (Figure 1c). This is in accordance with the general explanation of highest species richness in the presence of climatic optima (Rahbek 1995) and another study on a fog oasis in Northern Peru (Muenchow et al. 2013b).

\section{Floristic gradient and vegetation belts}

The NMDS ordination clearly captured the main floristic gradient with the first axis being overwhelmingly important (hypothesis 1). Consequently, the NMDS identifies altitude as the single most important predictor in explaining the vegetation composition. Our results reveal that altitude reflects levels of water availability and soil properties, which in turn define the classified vegetation belts. The perennial Tillandsia species of the lowermost class are typical representatives of vegetation formations found in fog oases. These perennial airplants are missing functional roots, and usually form patches on sandy habitats (Pinto et al. 2006, Rundel \& Dillon 1998). Higher up, individuals of Nolana humifusa, a species endemic to South American fog oases, indicate arid to semi-arid conditions (Dillon 2005). The bromeliad belt is the most humid vegetation belt, and thus harbours the highest number of species. In addition, it is also the belt with the best-developed and most nutrient-rich soils. Dillon \& Rundel (1990) refer to this belt as the woody species belt. This is confirmed by our results, as we recorded the highest number of woody species in this belt. However, trees were almost completely missing. We attribute this to human activity such as firewood harvesting (Dillon et al. 2003). Increasingly arid conditions prevail in the uppermost belt, which is visible in the appearance of initial soils and the adaptation to drought conditions of perennial plants.

Our model-based cluster approach confirms the schematically described vegetation belts of fog oasis formations (Dillon \& Rundel 1990, Ono 1986). A study from another fog oasis in Northern Peru reported five vegetation belts (Muenchow et al. 2013b). In the case of Mount Campana, the transition from bromeliad belt to adjacent vegetation belts is gradual. By contrast, these transition zones are more distinct on the Mount Mongón, and therefore identified as individual vegetation belts.

\section{Interpretation of the influence of soil predictors}

All soil variables chosen by our model reflect the altitudinal gradient, and consequently water availability in different ways (hypotheses $1 \& 2$ ). Concordantly, 
many studies confirmed water availability to be the most important limiting factor for primary production in arid to semi-arid environments (Espinosa et al. 2011, White \& Hood 2004, Whitford \& Steinberger 2011). However, soil properties might be equally important (Ronnenberg \& Wesche 2011, Whitford \& Steinberger 2011), and change along gradients (Wang et al. 2009).

In our study the sand fraction is the most important soil predictor. It steadily decreases with altitude until it meets the temperature inversion at about $850 \mathrm{~m}$ asl (Figure 1c). A low proportion of sand coincides with a high proportion of silt and clay. These fine grain sizes only develop if chemical weathering occurs, which in tropical climates mainly depend on water availability (Pope et al. 1995). A higher proportion of silt and clay provides properties beneficial to vegetation growth such as an increased capacity for storing water available to plants and the reversible storage of essential plant nutrients (Mengel \& Kirkby 2001). The fine-earth fraction exhibits a non-linear relationship with altitude (hypothesis 1), but is in general decreasing. Naturally, steeper slopes and rocky outcrops are more frequent with increasing altitude, thus explaining a lower percentage of the fineearth fraction at higher altitudes. By contrast, sandaccumulating winds form dune fields on gentle slopes at sea level. Electrical conductivity values peak at an altitudinal range between 300 and $550 \mathrm{~m}$ asl. The ionic concentrations of fogs might be one source of supplying the mountain slope with sulphate. However, this factor might be less effective than previously thought (Eckardt et al. 2013). Other salt sources might include bedrock weathering and dust storms (Viles \& Goudie 2013). Whatever the source, ionic concentrations are highest where moisture thresholds are crossed that allow the hydration and crystallization of common desert salts such as sodium sulphate (Viles \& Goudie 2013). This is most likely below the temperature inversion in our study area. Subsequently, these salts are probably transported downslope via interflow. Logically, humid air cannot pass the inversion. As a consequence lower electrical conductivity values occur at higher altitudes. High water infiltration rates and less fog occurrence may account for the low electrical conductivity values in the sandy lower part of the study area.

In concurrence with our results, soil texture and salinity are the most important soil physical properties influencing vegetation in arid environments (Abd ElGhani et al. 2011, Li et al. 2010). By contrast, soil nutrients appear to be more important in savannas (Sarmiento et al. 2006), tropical dry forests (Peña-Claros et al. 2012) and tropical montane forests (Soethe et al. 2008). Nevertheless, nutrients most definitely influence plant growth in fog oases. For instance, González et al. (2011) have shown how fog supplies bromeliads with nutrients in Chile.

\section{CONCLUSIONS}

This study tackled several key topics in biogeography and ecology. Species richness shows a mid-domain peak along the altitudinal gradient of our study area, which we explain by highest water availability at mid-elevations. We identify four vegetation belts along this climaticaltitudinal gradient. Additionally, we relate soil properties to the vegetation composition of a fog oasis for the first time. Soil variables, rendered significant by our statistical analyses, are also dependent on altitude, and thus water availability. Finally, we tentatively argue that both El Niño as well as La Niña events are beneficial for biomass production in fog oases.

The vegetation formations of Mount Campana might face extinction due to increased human activity on its slopes and in its immediate vicinity in the near future (http://www.chavimochic.gob.pe). However, human activities must not necessarily preclude the protection of highly diverse ecosystems, as demonstrated by examples from Thailand (Barbier et al. 2008) and Mexico (Cortina-Villar et al. 2012), and the concept of ecosystem services (Viglizzo et al. 2012) show. Therefore, it is still possible to protect this unique and very sensitive ecosystem, and, most importantly, the most diverse fog oasis in the world with its high portion of endemic species (Figure 1d; Dillon \& Rundel 1990).

\section{ACKNOWLEDGEMENTS}

We are deeply thankful for the funding granted by the Deutsche Forschungemeinschaft (project Ri $370 / 19-1)$. We greatly appreciate the comments and recommendations of the anonymous reviewer which helped to improve the manuscript. Also we would like to thank the Land Processes Distributed Active Archive Center of the NASA (https://lpdaac.usgs.gov/) for providing remote sensing imagery (ASTER, Landsat). Furthermore, we are indebted to Dr Ute Schmidt and Roswitha Höfner-Stich (both Erlangen) for their indispensable and kind support in the soil laboratory. Finally, we are most grateful to Dr Michael Richter for arousing our interest in Lomas formations.

\section{LITERATURE CITED}

ABD EL-GHANI, M., ABO EL-KHEIR, M., ABDEL-DAYEM, M. \& ABD ELHAMID, M. 2011. Vegetation analysis and soil characteristics of five common desert climbing plants in Egypt. Turkish Journal of Botany 35:561-580.

AH-PENG, C., WILDING, N., KLUGE, J., DESCAMPS-JULIEN, B., BARDAT, J., CHUAH-PETIOT, M., STRASBERG, D. \& HEDDERSON, T. A. J. 2012. Bryophyte diversity and range size distribution along two altitudinal gradients: continent vs. island. Acta Oecologica 42:58-65. 
ASHTON, P. S. 2003. Floristic zonation of tree communities on wet tropical mountains revisited. Perspectives in Plant Ecology, Evolution and Systematics 6:87-104.

BARBIER, E. B., KOCH, E. W., SILLIMAN, B. R., HACKER, S. D., WOLANSKI, E., PRIMAVERA, J., GRANEK, E. F., POLASKY, S., ASWANI, S., CRAMER, L. A., STOMS, D. M., KENNEDY, C. J., BAEL, D., KAPPEL, C. V., PERILLO, G. M. E. \& REED, D. J. 2008. Coastal ecosystem-based management with nonlinear ecological functions and values. Science 319:321-323.

BECK, E., BENDIX, J., KOTTKE, I., MAKESCHIN, F. \& MOSANDL, R. (eds.) 2008. Gradients in a tropical mountain ecosystem of Ecuador. Springer, Berlin. 542 pp.

BENDIX, J., TRACHTE, K., PALACIOS, E., ROLLENBECK, R., GÖTTLICHER, D., NAUSS, T. \& BENDIX, A. 2011. El Niño meets La Niña - anomalous rainfall patterns in the "traditional" El Niño region of Southern Ecuador. Erdkunde 65:151-167.

BLUNDO, C., MALIZIA, L. R., BLAKE, J. G. \& BROWN, A. D. 2012. Tree species distribution in Andean forests: influence of regional and local factors. Journal of Tropical Ecology 28:83-95.

BORCARD, D., LEGENDRE, P. \& DRAPEAU, P. 1992. Partialling out the spatial component of ecological variation. Ecology 73:10451055 .

BREHM, G., COLWELL, R. K. \& KLUGE, J. 2007. The role of environment and mid-domain effect on moth species richness along a tropical elevational gradient. Global Ecology and Biogeography 16:205219.

COLWELL, R. K., RAHBEK, C. \& GOTELLI, N. J. 2004. The mid-domain effect and species richness patterns:what have we learned so far? American Naturalist 163:E1-23.

CORTINA-VILLAR, S., PLASCENCIA-VARGAS, H., VACA, R., SCHROTH, G., ZEPEDA, Y., SOTO-PINTO, L. \& NAHED-TORAL, J. 2012. Resolving the conflict between ecosystem protection and land use in protected areas of the Sierra Madre de Chiapas, Mexico. Environmental Management 49:649-662.

DILLON, M. O. 2005. The Solanaceae of the Lomas formations of coastal Peru and Chile. Pp. 131-155 in Keating, R. C., Hollowell, V. C. \& Croat, T. B. (eds.). A Festschrift for William G. D’Arcy. Missouri Botanical Garden, St. Louis.

DILLON, M. O. \& RUNDEL, P. W. 1990. The botanical response of the Atacama and Peruvian Desert floras to the 1982-83 El Niño event. Pp. 487-504 in Glynn, P. W. (ed.). Global ecological consequences of the 1982-83 El Niño Southern Oscillation. Elsevier Oceanographic Series 52, Amsterdam.

DILLON, M. O., NAKAZAWA, M. \& LEIVA, S. G. 2003. The Lomas formations of coastal Peru: composition and biogeographic history. Pp. 1-9 in Haas, J. \& Dillon, M. O. (eds.). El Nino in Peru: biology and culture over 10,000 years. Field Museum of Natural History, Chicago.

ECKARDT, F. D., SODERBERG, K., COOP, L. J., MULLER, A. A., VICKERY, K. J., GRANDIN, R. D., JACK, C., KAPALANGA, T. S. \& HENSCHEL, J. 2013. The nature of moisture at Gobabeb, in the central Namib Desert. Journal of Arid Environments 93:7-19.

ESPINOSA, C. I., CABRERA, O., LUZURIAGA, A. L. \& ESCUDERO, A. 2011. What factors affect diversity and species composition of endangered Tumbesian dry forests in Southern Ecuador? Biotropica $43: 15-22$.
FRALEY, C. \& RAFTERY, A. E. 2002. Model-based clustering, discriminant analysis, and density estimation. Journal of the American Statistical Association 97:611-631.

GONZÁLEZ, A. L., FARINA, J. M., PINTO, R., PEREZ, C., WEATHERS, K. C., ARMESTO, J. J. \& MARQUET, P. A. 2011. Bromeliad growth and stoichiometry: responses to atmospheric nutrient supply in fog-dependent ecosystems of the hyper-arid Atacama Desert, Chile. Oecologia 167:835-845.

GRYTNES, J. A. 2003. Ecological interpretations of the mid-domain effect. Ecology Letters 6:883-888.

GRYTNES, J. A. \& BEAMAN, J. H. 2006. Elevational species richness patterns for vascular plants on Mount Kinabalu, Borneo. Journal of Biogeography 33:1838-1849.

HILL, M. O. \& GAUCH, H. G. 1980. Detrended Correspondence Analysis: an improved ordination technique. Vegetatio 42:47-58.

KATTAN, G. H. \& FRANCO, P. 2004. Bird diversity along elevational gradients in the Andes of Colombia: area and mass effects. Global Ecology and Biogeography 13:451-458.

KESSLER, M. 2001. Pteridophyte species richness in Andean forests in Bolivia. Biodiversity and Conservation 10:1473-1495.

KRUSKAL, J. B. 1964. Multidimensional scaling by optimizing goodness of fit to a nonmetric hypothesis. Psychometrika 29:1-27.

LALLEY, J. S. \& VILES, H. A. 2005. Terricolous lichens in the northern Namib Desert of Namibia: distribution and community composition. Lichenologist 37:77-91.

LAURANCE, S. G. W., LAURANCE, W.F., ANDRADE, A., FEARNSIDE, P. M., HARMS, K. E., VICENTINI, A. \& LUIZAO, R. C. C. 2010. Influence of soils and topography on Amazonian tree diversity: a landscapescale study. Journal of Vegetation Science 21:96-106.

LI, J., ZHAO, C. Y., SONG, Y. J., SHENG, Y. \& ZHU, H. 2010. Spatial patterns of desert annuals in relation to shrub effects on soil moisture. Journal of Vegetation Science 21:221-232.

LIU, W. J., MENG, F. R., ZHANG, Y. P., LIU, Y. H. \& LI, H. M. 2004. Water input from fog drip in the tropical seasonal rain forest of Xishuangbanna, South-West China. Journal of Tropical Ecology 20:517-524.

LOPEZ, B. C., RODRIGUEZ, R., GRACIA, C. A. \& SABATÉ, S. 2006. Climatic signals in growth and its relation to ENSO events of two Prosopis species following a latitudinal gradient in South America. Global Change Biology 12:897-906.

MENGEL, K. \& KIRKBY, E. A. 2001. Principles of plant nutrition. Fifth edition. Kluwer Academic Publishers, Dordrecht. 849 pp.

MUENCHOW, J., BRENNING, A. \& RICHTER, M. 2012. Geomorphic process rates of landslides along a humidity gradient in the tropical Andes. Geomorphology 139-140:271-284.

MUENCHOW, J., FEILHAUER, H., BRÄUNING, A., RODRÍGUEZ, E. F., BAYER, F., RODRÍGUEZ, R. A. \& VON WEHRDEN, H. 2013 a. Coupling ordination techniques and GAM to spatially predict vegetation assemblages along a climatic gradient in an ENSO-affected region of extremely high climate variability. Journal of Vegetation Science. doi: $10.1111 /$ jvs.12038.

MUENCHOW, J., BRÄUNING, A., RODRÍGUEZ, E. F. \& VON WEHRDEN, H. 2013b. Predictive mapping of species richness and plant species' distributions of a Peruvian fog oasis. Biotropica. doi: 10.1111/btp.12049. 
ONO, M. 1986. Definition, classification and taxonomic significance of the lomas vegetation. Pp. 5-14 in Ono, M. (ed.). Taxonomic and ecological studies on the Lomas vegetation in the Pacific coast of Peru. Tokyo Metropolitan University Makino Herbarium, Tokyo.

PAGE, A. L., BLACK, C. A., MILLER, R. H. \& KLUTE, A. 1982. Methods of soil analysis: Part 2. Chemical and microbiological properties. Second edition. American Society of Agronomy, Madison, WI.

PEÑA-CLAROS, M., POORTER, L., ALARCON, A., BLATE, G., CHOQUE, U., FREDERICKSEN, T. S., JUSTINIANO, M. J., LEANO, C., LICONA, J. C., PARIONA, W., PUTZ, F. E., QUEVEDO, L. \& TOLEDO, M. 2012. Soil effects on forest structure and diversity in a moist and a dry tropical forest. Biotropica 44:276-283.

PINTO, R., BARRIA, I. \& MARQUET, P. A. 2006. Geographical distribution of Tillandsia lomas in the Atacama Desert, northern Chile. Journal of Arid Environments 65:543-552.

PITMAN, N. C. A., WIDMER, J., JENKINS, C. N., STOCKS, G., SEALES, L., PANIAGUA, F. \& BRUNA, E. M. 2011. Volume and geographical distribution of ecological research in the Andes and the Amazon, 1995-2008. Tropical Conservation Science 4:64-81.

POPE, G. A., DORN, R. I. \& DIXON, J. C. 1995. A new conceptual model for understanding geographical variations in weathering. Annals of the Association of American Geographers 85:38-64.

RAHBEK, C. 1995. The elevational gradient of species richness: a uniform pattern? Ecography 18:200-205.

RAHBEK, C. 2005. The role of spatial scale and the perception of largescale species-richness patterns. Ecology Letters 8:224-239.

RAHBEK, C. \& GRAVES, G. R. 2001. Multiscale assessment of patterns of avian species richness. Proceedings of the National Academy of Sciences USA 98:4534-4539.

RODRÍGUEZ, L. C. 1996. Lomas del Cerro Campana: estudio geológico y geomorfológico. Arnaldoa 4:95-101.

ROLLENBECK, R., BENDIX, J. \& FABIAN, P. 2011. Spatial and temporal dynamics of atmospheric water inputs in tropical mountain forests of South Ecuador. Hydrological Processes 25:344-352.

RONNENBERG, K. \& WESCHE, K. 2011. Effects of fertilization and irrigation on productivity, plant nutrient contents and soil nutrients in southern Mongolia. Plant and Soil 340:239-251.

RUNDEL, P. W. 1978. Ecological relationships of desert fog zone lichens. Bryologist 81:277-293.

RUNDEL, P. W. \& DILLON, M. O. 1998. Ecological patterns in the Bromeliaceae of the lomas formations of Coastal Chile and Peru. Plant Systematics and Evolution 212:261-278.

SAGÁSTEGUI, A., MOSTACERO, J. \& LOPEZ, S. 1988. Fitoecología del Cerro Campana (Provincia de Trujillo). Boletín de la Sociedad Botánica de la Libertad 14:1-47.

SARKAR,D. 2008. Lattice: multivariate data visualization with R. Springer, New York. 296 pp.

SANCHEZ-CORDERO, V. 2001. Elevation gradients of diversity for rodents and bats in Oaxaca, Mexico. Global Ecology and Biogeography 10:63-76.

SANDEL, B. S. \& MCKONE, M. J. 2006. Reconsidering null models of diversity: do geometric constraints on species ranges necessarily cause a mid-domain effect? Diversity and Distributions 12:467474 .
SARMIENTO, G., DA SILVA, M. P., NARANJO, M. E. \& PINILLOS, M. 2006. Nitrogen and phosphorus as limiting factors for growth and primary production in a flooded savanna in the Venezuelan Llanos. Journal of Tropical Ecology 22:203-212.

SCHLICHTING, E., BLUME, H.-P. \& STAHR, K. 1995. Bodenkundliches Praktikum: eine Einführung in pedologisches Arbeiten für Ökologen, insbesondere Land- und Forstwirte, und für Geowissenschaftler. Second revised edition. Blackwell Wissenschafts-Verlag, Berlin. 295 pp.

SCHULZ, N., ACEITUNO, P. \& RICHTER, M. 2011. Phytogeographic divisions, climate change and plant dieback along the coastal desert of Northern Chile. Erdkunde 65:169-187.

SITTERS, J., HOLMGREN, M., STOORVOGEL, J. J. \& LOPEZ, B. C. 2012. Rainfall-tuned management facilitates dry forest recovery. Restoration Ecology 20:33-42.

SOETHE, N., LEHMANN, J. \& ENGELS, C. 2008. Nutrient availability at different altitudes in a tropical montane forest in Ecuador. Journal of Tropical Ecology 24:397-406.

SQUEO, F. A., TRACOL, Y., LÓPEZ, D., GUTIÉRREZ, J. R., CORDOVA, A. M. \& EHLERINGER, J. R. 2006. ENSO effects on primary productivity in Southern Atacama desert. Advances in Geosciences 6:1-28.

TERBORGH, J. 1971. Distribution on environmental gradients: theory and a preliminary interpretation of distributional patterns in the avifauna of the Cordillera Vilcabamba, Peru. Ecology 52:2340 .

TUOMISTO, H., POULSEN, A. D., RUOKOLAINEN, K., MORAN, R. C., QUINTANA, C., CELI, J. \& CANAS, G. 2003. Linking floristic patterns with soil heterogeneity and satellite imagery in Ecuadorian Amazonia. Ecological Applications 13:352-371.

VIGLIZZO, E. F., PARUELO, J. M., LATERRA, P. \& JOBBAGY, E. G. 2012. Ecosystem service evaluation to support land-use policy. Agriculture Ecosystems and Environment 154:78-84.

VILES, H. A. \& GOUDIE, A. S. 2013. Weathering in the central Namib Desert, Namibia: controls, processes and implications. Journal of Arid Environments 93:20-29.

WANG, Z. M., ZHANG, B., SONG, K. S., LIU, D. W., REN, C. Y., ZHANG, S. M., HU, L. J., YANG, H. J. \& LIU, Z. M. 2009. Landscape and land-use effects on the spatial variation of soil chemical properties. Communications in Soil Science and Plant Analysis 40:23892412.

WESCHE, K. \& WEHRDEN, H. 2011. Surveying Southern Mongolia: application of multivariate classification methods in drylands with low diversity and long floristic gradients. Applied Vegetation Science 14:561-570.

WHITE, D. A. \& HOOD, C. S. 2004. Vegetation patterns and environmental gradients in tropical dry forests of the northern Yucatan Peninsula. Journal of Vegetation Science 15:151-160.

WHITFORD, W. G. \& STEINBERGER, Y. 2011. Effects of simulated storm sizes and nitrogen on three Chihuahuan Desert perennial herbs and a grass. Journal of Arid Environments 75:861-864.

WHITTAKER, R. H. 1972. Evolution and measurement of species diversity. Taxon 21:213-251.

WHITTAKER, R. H. \& NIERING, W. 1965. Vegetation of the Santa Catalina Mountains, Arizona: a gradient analysis of the south slope. Ecology 46:429-452. 


\section{RESUMEN}

El estudio de recambio de especies a lo largo de gradientes es un tema clave en la ecología tropical. Los conductores cruciales, entre otros, son la deposición de niebla y las propiedades del suelo. En el norte de Perú, una formación vegetal dependiente de las nubes estratos se desarrolla en las montañas a lo largo de la costa hiperárida. A pesar de su singularidad, estos oasis de niebla están en gran parte sin investigar. Este estudio aborda la influencia de los factores ambientales sobre la vegetación de estos oasis de niebla únicos. En consecuencia, las propiedades de la vegetación y el suelo se registraron en 66 parcelas de $4 \times 4-\mathrm{m}$ a lo largo de un gradiente altitudinal que oscila entre 200 y 950 m.s.n.m. Técnicas de ordenación y modelos fueron utilizados para estudiar los cinturones altitudinales de vegetación y composición florística. Se identificaron cuatro pisos de vegetación: a baja altitud un cinturón de Tillandsia, un cinturón de herbáceas, luego un cinturón de bromelias mostrando elevada riqueza de especies y finalmente un cinturón en la parte superior constituido por suculentas. Los diferentes niveles altitudinales podrían reflejar la disponibilidad de agua, la cual es más alta por debajo de la inversión de temperatura a unos 700 m.s.n.m. La altitud sola explicó el 96\% de la composición florística. La textura del suelo y la salinidad representaron el $88 \%$. Esto está en contraste con los ecosistemas tropicales más húmedos donde los nutrientes del suelo aparecen ser más importantes. En conclusión, este estudio ayuda a la comprensión de los gradientes en los ecosistemas tropicales tanto de los dependientes de la niebla así como de los afectados por ENSO.

Appendix 1. List of all species found on Mount Campana during the study period (August-September 2011) including frequency (\%) over all plots and median and maximal observed plot abundance (\%). Nomenclature follows the Missouri Botanical Garden Tropicos online database (http://www.tropicos.org/).

\begin{tabular}{|c|c|c|c|}
\hline Species & Frequency & Median abundance & Maximal abundance \\
\hline Adiantum subvolubile (Pteridaceae) & 3 & 0 & 0.5 \\
\hline Ageratina azangaroensis (Asteraceae) & 7.6 & 0 & 16.0 \\
\hline Alonsoa meridionalis (Scrophulariaceae) & 21.2 & 0 & 1.5 \\
\hline Alternanthera halimifolia (Amaranthaceae) & 48.5 & 0 & 7.0 \\
\hline Apodanthera ferreyrana (Cucurbitaceae) & 1.5 & 0 & 1.5 \\
\hline Astrephia chaerophylloides (Caprifoliaceae) & 18.2 & 0 & 15.0 \\
\hline Atriplex rotundifolia (Amaranthaceae) & 21.2 & 0 & 8.0 \\
\hline Baccharis arenaria (Asteraceae) & 9.1 & 0 & 4.0 \\
\hline Begonia acutitepala (Begoniaceae) & 9.1 & 0 & 5.0 \\
\hline Begonia octopetala (Begoniaceae) & 4.5 & 0 & 1.0 \\
\hline Bowlesia palmata (Apiaceae) & 6.1 & 0 & 12.0 \\
\hline Calandrinia alba (Montiaceae) & 6.1 & 0 & 1.0 \\
\hline Calceolaria pinnata (Calceolariaceae) & 40.9 & 0 & 20.0 \\
\hline Calceolaria utricularioides (Calceolariaceae) & 18.2 & 0 & 4.0 \\
\hline Chionopappus benthamii (Asteraceae) & 3 & 0 & 1.0 \\
\hline Ciclospermum laciniatum (Apiaceae) & 62.1 & 0.1 & 2.0 \\
\hline Cistanthe paniculata (Montiaceae) & 21.2 & 0 & 1.0 \\
\hline Colicodendron scabridum (Cleomaceae) & 1.5 & 0 & 1.0 \\
\hline Cordia macrocephala (Boraginaceae) & 3 & 0 & 7.0 \\
\hline Crassula connata (Crassulaceae) & 19.7 & 0 & 0.5 \\
\hline Cremolobus parviflorus (Brassicaceae) & 3 & 0 & 0.5 \\
\hline Cryptantha parviflora (Boraginaceae) & 1.5 & 0 & 0.1 \\
\hline Cyclanthera mathewsii (Cucurbitaceae) & 7.6 & 0 & 1.0 \\
\hline Dalea nova (Fabaceae) & 4.5 & 0 & 3.0 \\
\hline Dicliptera peruviana (Acanthaceae) & 15.2 & 0 & 4.0 \\
\hline Drymaria cordata (Caryophyllaceae) & 50 & 0 & 25.0 \\
\hline Drymaria rotundifolia (Caryophyllaceae) & 21.2 & 0 & 7.0 \\
\hline Eremocharis longiramea (Apiaceae) & 1.5 & 0 & 0.5 \\
\hline Erigeron leptorhizon (Asteraceae) & 10.6 & 0 & 1.0 \\
\hline Erodium sp. (Geraniaceae) & 1.5 & 0 & 0.5 \\
\hline Espostoa lanata (Cactaceae) & 3 & 0 & 6.0 \\
\hline Euphorbia viridis (Euphorbiaceae) & 48.5 & 0 & 5.0 \\
\hline Fuertesimalva limensis (Malvaceae) & 74.2 & 0.5 & 12.0 \\
\hline Fuertesimalva peruviana (Malvaceae) & 3 & 0 & 0.1 \\
\hline Furcraea occidentalis (Asparagaceae) & 9.1 & 0 & 9.0 \\
\hline Geranium limae (Geraniaceae) & 7.6 & 0 & 3.0 \\
\hline Haageocereus decumbens (Cactaceae) & 24.2 & 0 & 5.0 \\
\hline Haageocereus pacalaensis (Cactaceae) & 12.1 & 0 & 1.5 \\
\hline Ipomoea dumetorum (Convolvulaceae) & 12.1 & 0 & 1.0 \\
\hline Ipomoea purpurea (Convolvulaceae) & 1.5 & 0 & 0.5 \\
\hline Ipomoea sp. (Convolvulaceae) & 45.5 & 0 & 5.0 \\
\hline
\end{tabular}


Appendix 1. Continued.

\begin{tabular}{|c|c|c|c|}
\hline Species & Frequency & Median abundance & Maximal abundance \\
\hline Lantana scabiosiflora (Verbenaceae) & 6.1 & 0 & 1.5 \\
\hline Lycianthes lycioides (Solanaceae) & 6.1 & 0 & 15.0 \\
\hline Lycium americanum (Solanaceae) & 30.3 & 0 & 6.0 \\
\hline Nicandra physalodes (Solanaceae) & 1.5 & 0 & 0.1 \\
\hline Nicotiana paniculata (Solanaceae) & 37.9 & 0 & 5.0 \\
\hline Nolana humifusa (Solanaceae) & 80.3 & 2 & 25.0 \\
\hline Ophryosporus hartwegii (Asteraceae) & 7.6 & 0 & 10.0 \\
\hline Ophryosporus peruvianus (Asteraceae) & 7.6 & 0 & 5.0 \\
\hline Oxalis corniculata (Oxalidaceae) & 6.1 & 0 & 0.2 \\
\hline Oxalis megalorrhiza (Oxalidaceae) & 65.2 & 0.5 & 13.0 \\
\hline Palaua malvifolia (Malvaceae) & 4.5 & 0 & 0.1 \\
\hline Parietaria debilis (Urticaceae) & 77.3 & 0.8 & 6.0 \\
\hline Paspalum racemosum (Poaceae) & 21.2 & 0 & 6.0 \\
\hline Pelexia matucanensis (Orchidaceae) & 21.2 & 0 & 2.0 \\
\hline Peperomia dolabriformis (Piperaceae) & 13.6 & 0 & 5.0 \\
\hline Peperomia galioides (Piperaceae) & 48.5 & 0 & 7.0 \\
\hline Philoglossa purpureodisca (Asteraceae) & 62.1 & 3 & 35.0 \\
\hline Pitcairnia lopezii (Bromeliaceae) & 51.5 & 0.5 & 28.0 \\
\hline Plantago limensis (Plantaginaceae) & 1.5 & 0 & 2.0 \\
\hline Polypodium lasiopus (Polypodiaceae) & 4.5 & 0 & 1.0 \\
\hline Polypogon interruptus (Poaceae) & 63.6 & 1 & 7.0 \\
\hline Puya ferruginea (Bromeliaceae) & 62.1 & 4 & 50.0 \\
\hline Racinaea multiflora (Bromeliaceae) & 53 & 1 & 40.0 \\
\hline Salvia tubiflora (Lamiaceae) & 6.1 & 0 & 8.0 \\
\hline Sarcostemma solanoides (Apocynaceae) & 3 & 0 & 0.5 \\
\hline Senecio truxillensis (Asteraceae) & 36.4 & 0 & 10.0 \\
\hline Sicyos baderoa (Cucurbitaceae) & 15.2 & 0 & 8.0 \\
\hline Solanum montanum (Solanaceae) & 81.8 & 1 & 9.0 \\
\hline Solanum habrochaites (Solanaceae) & 10.6 & 0 & 3 \\
\hline Solanum mochiquense (Solanaceae) & 4.5 & 0 & 0.8 \\
\hline Solanum multifidum (Solanaceae) & 4.5 & 0 & 3.0 \\
\hline Sonchus oleraceus (Asteraceae) & 47 & 0 & 7.0 \\
\hline Stellaria cuspidata (Caryophyllaceae) & 13.6 & 0 & 4.0 \\
\hline Stipa ichu (Poaceae) & 1.5 & 0 & 1.0 \\
\hline Tetragonia crystallina (Aizoaceae) & 1.5 & 0 & 0.5 \\
\hline Tillandsia disticha (Bromeliaceae) & 1.5 & 0 & 0.5 \\
\hline Tillandsia latifolia (Bromeliaceae) & 62.1 & 1 & 30.0 \\
\hline Tillandsia purpurea (Bromeliaceae) & 30.3 & 0 & 45.0 \\
\hline Tillandsia recurvata (Bromeliaceae) & 12.1 & 0 & 14.0 \\
\hline Tournefortia microcalyx (Boraginaceae) & 3 & 0 & 0.5 \\
\hline Trixis cacalioides (Asteraceae) & 1.5 & 0 & 0.5 \\
\hline Tropaeolum peltophorum (Tropaeolaceae) & 6.1 & 0 & 0.5 \\
\hline unknown Scrophulariaceae & 1.5 & 0 & 0.0 \\
\hline Valeriana pinnatifida (Caprifoliaceae) & 30.3 & 0 & 6.0 \\
\hline Vasquezia oppositifolia (Asteraceae) & 3 & 0 & 4.0 \\
\hline Verbesina saubinetioides (Asteraceae) & 68.2 & 4 & 40.0 \\
\hline Wedelia latifolia (Asteraceae) & 45.5 & 0 & 15.0 \\
\hline
\end{tabular}

